\title{
Amino acid incorporation into proteins of human normal and ulcerative colitis colonic mucosa ${ }^{1}$
}

\author{
MARTIN BROTMAN \\ From the Gastroenterology Unit, Mayo Clinic, and the Mayo Graduate School of Medicine \\ (University of Minnesota), Rochester, Minnesota, USA
}

Whole-cell proliferation kinetics have been measured in vivo in the colon and rectum of 'normal' man (Lipkin, Bell, and Sherlock, 1963) and in vitro in the rectal mucosa from patients with ulcerative colitis (Shorter, Spencer, and Hallenbeck, 1966). These studies demonstrated delayed mucosal cell turnover in the diseased mucosa. Failure of regeneration of epithelial cells may be a factor in the pathogenesis of the persistent mucosal lesion in ulcerative colitis (Lumb and Protheroe, 1955) because numerous studies have demonstrated rapid regeneration of colonic mucosa after other types of injury (Braucher and Kirsner, 1962 and 1966; Foley and Wattenberg, 1960; McMinn and Johnson, 1958; Melnyk, Braucher, and Kirsner, 1966). Lipkin and Quastler (1962) demonstrated that rapid protein synthesis occurs in proliferating intestinal epithelial cells. Rates of protein biosynthesis have been measured in the colon and rectum of the rat (Lipkin and Quastler, 1962) but no similar information is available in human normal or ulcerative colitis mucosa.

In this study, rates of incorporation of ${ }^{14} \mathrm{C}$ labelled amino acids into human normal and ulcerative colitis colonic mucosal proteins were measured in vitro.

\section{MATERIALS AND METHODS}

TISSUE Fresh sigmoid colon was obtained either from histologically normal colon adjacent to a segment resected because of malignancy or at proctocolectomy for ulcerative colitis. The specimen was immediately immersed in ice-cold Krebs-Ringer bicarbonate solution (Umbreit, Burris, and Stauffer, 1964) containing 0.5\% glucose. The segment was opened lengthwise, pinned flat, and rinsed clean with physiological saline. The mucosa was separated by blunt dissection and immersed in ice-cold Krebs-Ringer solution containing $0.5 \%$ glucose. A part of each specimen was examined histologically.

'This investigation was supported in part by research grant AM-6908 and by training grant AM-5259 from the National Institutes of Health, Public Health Service.
AMINO ACID INCORPORATION INTO PROTEIN Approximately $100 \mathrm{mg}$ of mucosa was preincubated in an atmosphere of $95 \% \mathrm{O}_{2}$ (or $\mathrm{N}_{2}$ for anaerobic experiments) and $5 \% \mathrm{CO}_{2}$ at $37^{\circ} \mathrm{C}$ for three minutes in $25-\mathrm{ml}$ Erlenmeyer flasks containing $2.5 \mathrm{ml}$ of Krebs-Ringer solution and $0.2 \mathrm{ml}$ of $7.5 \%$ glucose solution. Amino acid-14 $\mathrm{C}$ mixture $\left(1.2 \times 10^{4} \mathrm{cpm}\right.$ in $0.3 \mathrm{ml}$ ) (purified mixture obtained from New England Nuclear Corporation, Boston; specific activity, $1.5 \mathrm{mc} / \mathrm{mg}$ ) was added to each flask to start the reaction. The reaction was stopped at an appropriate time by homogenizing the contents of the flask at 0 to $4^{\circ} \mathrm{C}$ in a tightly fitting Potter-Elvehjem homogenizer, followed by adding $3 \mathrm{ml}$ of $22.5 \%$ trichloroacetic acid containing $1 \%$ casamino acids. The precipitated protein samples were purified according to a modification of the procedure of Siekevitz (1952). The samples were plated and counted as described previously (Brotman, 1967).

\section{RESULTS}

The mucosal specimens were relatively free of submucosal tissue (Fig. 1), although it was more difficult to separate the diseased mucosa than the healthy mucosa.

The time course of amino acid incorporation into normal mucosal proteins is presented in Figure 2. An initial five to 10-minute lag phase of low activity was followed by linear incorporation to 60 to 70 minutes. The initial and terminal phases were not studied further. Mean specific radioactivity incorporated $(\mathrm{cpm} / \mathrm{mg} / 40 \mathrm{~min})$ in specimens from patients given antibiotics (neomycin, oxytetracycline) preoperatively was not significantly different from that in patients not so treated $(P>0 \cdot 10)$.

Incorporation was significantly reduced by the metabolic inhibitors dinitrophenol $\left(2 \times 10^{-4} \mathrm{M}\right)$ and cyanide $\left(2 \times 10^{-3} \mathrm{M}\right)$ and by anaerobic incubation (Fig. 3) $(\mathbf{P}<0.001)$.

To assess the rate of amino acid incorporation into proteins of bacterial contaminants, incubations were carried out with the addition of antibiotics. Penicillin (100 units/ml), chloramphenicol $(50 \mu \mathrm{g} /$ $\mathrm{ml})$, and streptomycin $(100 \mu \mathrm{g} / \mathrm{ml})$ did not significantly reduce incorporation (Fig. 3) $(P>0 \cdot 10)$. 

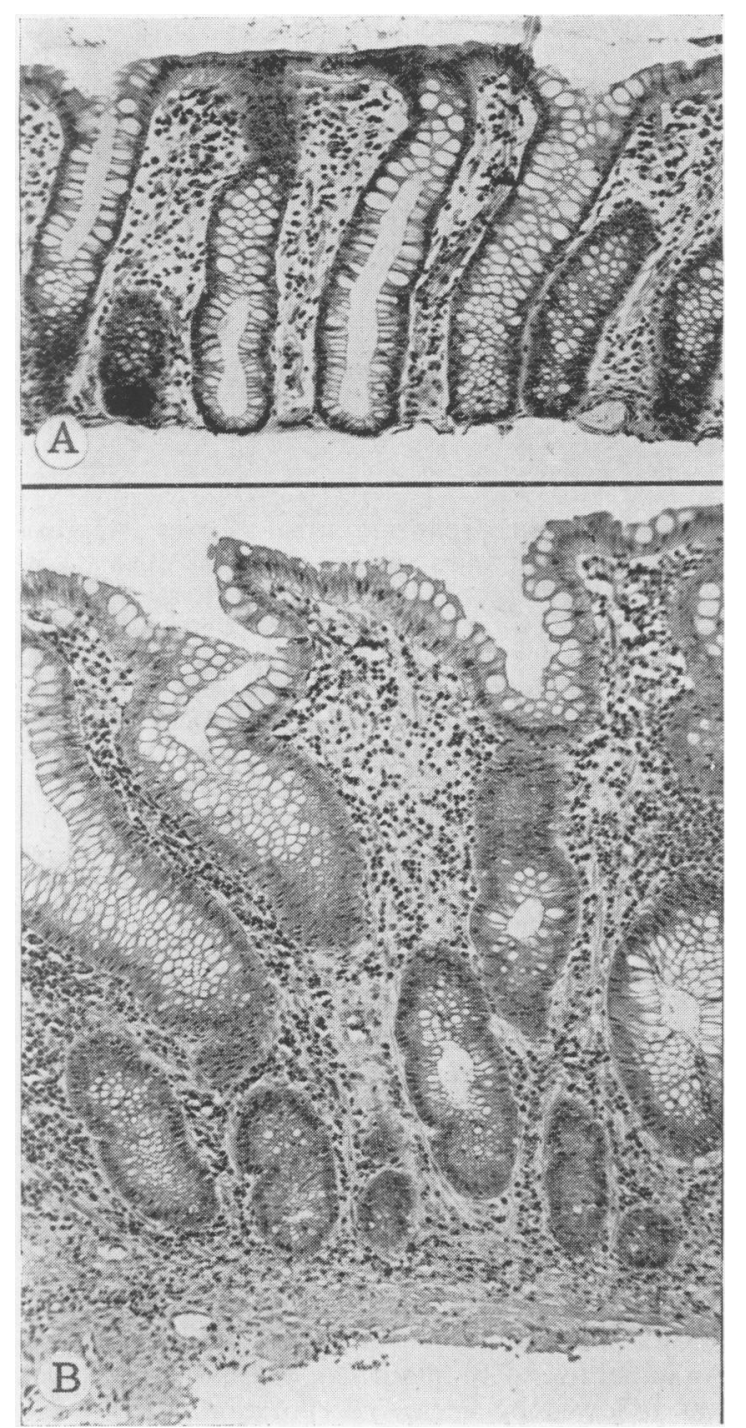

FIG. 1.

FIG. 1. Human mucosa as prepared in these experiments. $A$, normal; $B$, ulcerative colitis.

FIG. 2. Time course of incorporation of ${ }^{14} \mathrm{C}$-labelled amino acids into normal human colonic mucosal proteins.

FIG. 3. Effect of metabolic inhibitors and antibiotics on incorporation of ${ }^{14} \mathrm{C}$-labelled amino acids into human colonic mucosal proteins. Data shown as means $\pm S E$; number of observations shown in parentheses. $N=$ standard conditions; $\quad D N P=$ dinitrophenol; $C N^{-}=$cyanide; $A N=$ anaerobic incubation; $C H L=$ chloramphenicol; $P E N=$ penicillin $;$ STR $=$ streptomycin .

FIG. 4. Incorporation of ${ }^{14} \mathrm{C}$-labelled amino acids into mucosal proteins of 57 normal $(N)$ and 18 ulcerative colitis (UC) human colonic mucosal specimens during indubation for 40 miuutes. Data shown as means $\pm S E$.

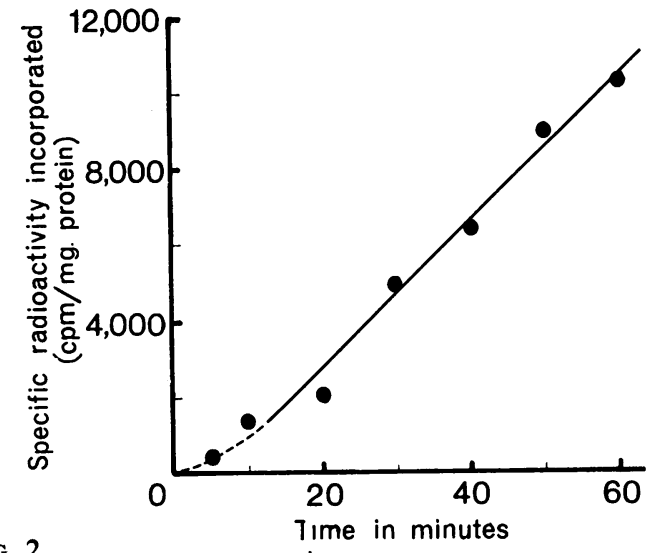

FIG. 2.

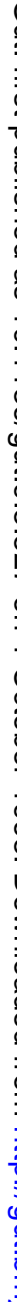

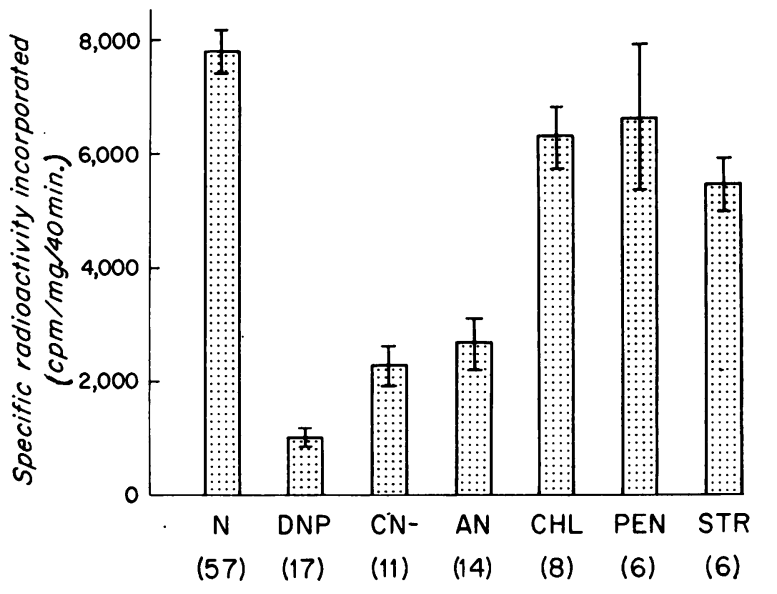

FIG. 3.

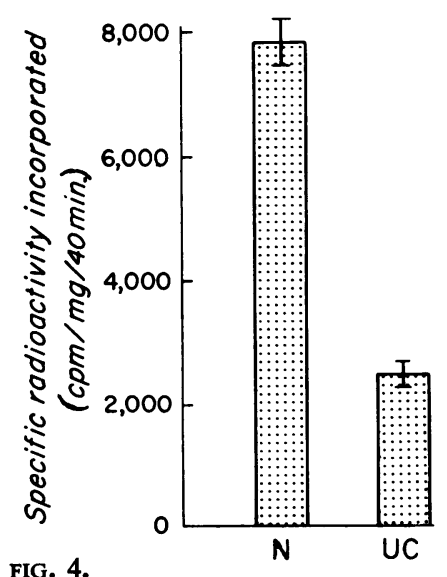

FIG. 4. 
Rates of incorporation (per milligram of protein) were significantly lower in 18 ulcerative colitis specimens than in 57 histologically normal specimens (Fig. 4) $(\mathrm{P}<0.001)$.

\section{DISCUSSION}

These studies demonstrate energy-dependent incorporation of amino acids into normal human colonic mucosal proteins in vitro and a markedly reduced incorporation rate in ulcerative colitis mucosa. Studies in the presence of antibiotics indicate that protein synthesis by extracellular bacterial contaminants probably does not contribute significantly to this system.

The rate of incorporation of labelled amino acids into epithelial protein is correlated with the rate of epithelial cell turnover (Lipkin and Quastler, 1962; Brotman, 1967). The diminished rate of protein synthesis shown in this study is in accordance with the prolonged epithelial cell turnover time in ulcerative colitis demonstrated by Shorter and his colleagues (1966) and may be a factor in the defective regenerative capacity of the mucosa (Dick, Holt, and Dalton, 1966). However, many factors influence the healing of diseased tissue, including primary intrinsic defects in cellular regenerative capacity and secondary defects due, for example, to systemic deficiencies (preoperative malnutrition, protein deficiency), local bacterial invasion, and interference with blood supply. Each of these factors may influence the results of this investigation. In addition, the effects of continuing catabolism, due to the primary unknown pathogenetic mechanism, may be very difficult to distinguish when anabolic processes are being studied. Similarly, in studying diseased tissues in unfractionated systems, the presence of large numbers of various types of cells not normally present complicates interpretation of data which represent net metabolic activities of all cell types. Inability to measure accurately the specific activity of the labelled precursor at the intracellular site for activation and incorporation into protein is an additional important consideration in the interpret- ation of studies of protein synthesis in unfractionated systems. Resolution of these problems awaits the development of techniques for the isolation and quantification of viable human colonic epithelial cells.

\section{SUMMARY}

Energy-dependent incorporation of ${ }^{14} \mathrm{C}$-labelled amino acids into human colonic mucosal proteins was demonstrated in vitro. Incorporation was significantly diminished in ulcerative colitis mucosa. These findings are consistent with defective regenerative capacity of the colonic mucosa in ulcerative colitis.

The technical assistance of Mrs Mary Ham is gratefully acknowledged.

\section{REFERENCES}

Braucher, R. E., and Kirsner, J. B. (1962). Regeneration of colon mucosa: a morphologic and histochemical study. Gastroenterology, 42, 706-717.

(1966). Regeneration of colon mucosa in large lesions: a morphological and histochemical study. Ibid., 50, 372-375.

Brotman, M. (1967). Amino acid incorporation in rat colonic epithelial proteins. Canad. J. Biochem., 45, 1633-1637.

Dick, A. P., Holt, L. P., and Dalton, E. R. (1966). Persistence of mucosal abnormality in ulcerative colitis. Gut, 7, 355-360.

Foley, W. A., and Wattenberg, L. W. (1960). A histochemical study of regenerating large bowel epithelium. Arch. Path. (Chic.), 70, 675-684.

Lipkin, M., Bell, B., and Sherlock, P. (1963). Cell proliferation kinetics in the gastrointestinal tract of man. 1. Cell renewal in colon and rectum. J. clin. Invest., 421, 767-776.

- , and Quastler, H. (1962). Studies of protein metabolism in intestinal epithelial cells. Ibid., 41, 646-653.

Lumb, G., and Protheroe, R. H. B. (1955). Biopsy of the rectum in ulcerative colitis. Lancet, 2, 1208-1215.

McMinn, R. M. H., and Johnson, F. R. (1958). Repair of wounds of the mucosa in the rectum of the cat. J. Embryol. exp. Morph. 6, 509-517.

Melnyk, C. S., Braucher, R. E., and Kirsner, J. B. (1966). Colon mucosa response to injury. 1. Morphological study. 2. Histochemical study. Gastroenterology, 51, 43-49; 50-58.

Shorter, R. G., Spencer, R. J., and Hallenbeck, G. A. (1966). Kinetic studies of the epithelial cells of the rectal mucosa in normal subjects and patients with ulcerative colitis. Gut, 7, 593-596.

Siekevitz, P. (1952). Uptake of radioactive alanine in vitro into the proteins of rat liver fractions. J. biol. Chem., 195, 549-565.

Umbreit, W. W., Burris, R. H., and Stauffer, J. F. (1964). Manometric Techniques: A Manual Describing Methods Applicable to the Study of Tissue Metabolism, 4th ed. Burgess, Minneapolis. 